Takumi Taniguchi $\mathrm{MD}$,

Ken Yamamoto MD, Tsutomu Kobayashi MD

\section{Precipitate formed by thiopentone and vecuronium causes pulmonary embolism}

Purpose: To examine the effects of a bolus injection of the precipitate formed by thiopentone and vecuronium on the pharmacokinetic behaviour of thiopentone, cardiopulmonary physiology, and lung histology.

Methods: Of 16 female rabbits ( 2.9 to $3.1 \mathrm{~kg}$ ), eight were injected with a precipitate formed by a mixture of $5 \mathrm{mg} \cdot \mathrm{kg}^{-1}$ thiopentone and $0.67 \mathrm{mg} \mathrm{kg}^{-1}$ vecuronium via the external jugular vein. Eight control rabbits were injected with $5 \mathrm{mg} \cdot \mathrm{kg}^{-1}$ thiopentone alone. Plasma thiopentone concentration, systolic arterial pressure and $\mathrm{PaO}_{2}$ were measured for $60 \mathrm{~min}$ after injection. Histological changes in the lungs were evaluated at one and $60 \mathrm{~min}$.

Results: Maximum blood thiopentone concentration in the precipitate group was lower than in the control group $(12.9 \pm 4.5 \mathrm{vs} 17.0 \pm 1.6 \mu \mathrm{g} \cdot \mathrm{ml}, P<0.05)$, although the half-life of thiopentone in the precipitate group was longer $(32.3 \pm 8.5$ vs $21.7 \pm 8.2 \mathrm{~min} . P<0.05)$ and the area under the time concentration curve was similar between the two groups. However, the mean residence time was $28 \%$ longer in the precipitate group than in controls $(P<0.05)$. The $\mathrm{PaO}_{2}$ was lower in the precipitate group than in controls one minute after injection (431 \pm 27 vs $464 \pm 18 \mathrm{mmHg}, P<0.05$ ) but not subsequently. Histologically, crystals (30-150 $\mu \mathrm{m}$ in diameter) obstructed small arteries in the lungs at one minute but not at 60 min after injection.

Conclusion: Intravenous injection of precipitate causes pulmonary microembolism, with a small transient decrease in $\mathrm{PaO}_{2}$.

Objectif : Évaluer l'effet de l'injection en bolus du précipité formé par le thiopental et le vécuronium sur la pharmacocinétique du thiopental, sur la physiologie cardio-pulmonaire et sur l'histologie pulmonaire.

Méthodes : D'un groupe de 16 lapins femelles $(2,9 \mathrm{a} 3,1 \mathrm{~kg}), 8$ ont reçu $N$ par la jugulaire exteme un précipité composé de $5 \mathrm{mg} \cdot \mathrm{kg}^{-1}$ de thiopental et de $0,67 \mathrm{mg} \cdot \mathrm{kg}^{-1}$ de vécuronium, alors que les 8 témoins n'ont reçu que du thiopental à la dose de $5 \mathrm{mg} \cdot \mathrm{kg}^{-1}$. Durant les 60 minutes suivant l'injection on a mesuré la concentration plasmatique de thiopental, la pression artérielle systolique et la $\mathrm{PaO}_{2}$. Les changements histologiques du poumon ont été évalués à une minute et à 60 min.

Résultats : La concentration sanguine maximale de thiopental était plus basse dans le groupe précipité que dans le groupe témoin $\left(12,9 \pm 4,5 \mathrm{vs} 17,0 \pm 1,6 \mu \mathrm{g} \cdot \mathrm{ml}^{-1}, P<0,05\right)$; cependant, la demi-vie du thiopental dans le groupe précipité était plus longue $(32,3 \pm 8,5$ vs $21,7 \pm 8,2 \mathrm{~min}, P<0,05)$ et la surface sous la courbe temps/concentration était similaire pour les deux groupes. Cependant le temps de rétention moyen était de $28 \%$ plus long dans le groupe précipité $(P<0,05)$. La $\mathrm{PaO}$, était plus basse dans le groupe précipité à I minute après l'injection ( $431 \pm 27$ vs $464 \pm 18 \mathrm{mmHg}, P<0,05)$ mais non par la suite. Histologiquement, des cristaux (30-150 $\mu \mathrm{m}$ de diamètre) obstruaient les petites artères des poumons à I minute après l'injection, mais n'étaient plus visibles à $60 \mathrm{~min}$.

Conclusion : Linjection intraveineuse de précipité cause des microembolies pulmonaires avec une baisse transitoire de la $\mathrm{PaO}_{2}$. 
EQUENTIAL intravenous injections of thiopentone and vecuronium produce a white precipitate. This precipitate may disturb the smooth induction of general anaesthesia if it occludes the infusion line. In a previous study, we observed that the precipitate was thiopentone acid, which is insoluble in human plasma. ${ }^{1}$ However, we did not describe the kinetics of the precipitate and the effects on cardiopulmonary function after the intravenous injection of the precipitate in pivo. Therefore, we have studied the pharmacokinetic behaviour of thiopentone, arterial blood gases, and histology after the injection of precipitate in rabbits.

\section{Methods}

With the approval of our institutional Animal Care Committee, we conducted this study in 24 female Japanese rabbits (2.9-3.1 kg body weight). In 16, we examined the pharmacokinetic behaviour of thiopentone, cardiopulmonary function, and pulmonary histological changes at $60 \mathrm{~min}$ after injection. In the other eight animals studied, histological examination was performed at one minute. After placement of an indwelling catheter into the right ear vein, anaesthesia was induced with $750 \mathrm{mg} \cdot \mathrm{kg}^{-1}$ urethane $i v$ and was maintained by its continuous infusion (100 mg.kg-1 $\left.\cdot \mathrm{hr}^{-1}\right)$. A tracheostomy was performed, and a tracheal tube was inserted. The lungs were mechanically ventilated with $\mathrm{SN}-480-5$ (Shinano, Tokyo, Japan) with oxygen to maintain $\mathrm{PaCO}_{2}$ at approximately $35 \mathrm{mmHg}$. A lead II ECG was used to record heart rate (HR). To monitor the systolic arterial pressure and to obtain blood, a catheter was inserted into the left carotid artery and connected to a polygraphic recorder (Nihon Kohden, Tokyo, Japan). Arterial blood gas analysis was performed with ABL-3 (Radiometer, Copenhagen, Denmark). A polyethylene 16-G catheter was inserted into the right external jugular vein for the bolus injection of drugs.

After the surgical procedure, the animals rested for at least $15 \mathrm{~min}$ to allow stabilisation. Baseline readings of HR and systolic arterial pressure were then taken. Following baseline measurement, the animals were randomly allocated to one of two groups. A precipitate group $(n=8)$ received a bolus injection of a mixture $(2 \mathrm{ml})$ of $5 \mathrm{mg} \cdot \mathrm{kg}^{-1}$ thiopentone and 0.67 $\mathrm{mg} \cdot \mathrm{kg}^{-1}$ vecuronium. The control group $(\mathrm{n}=8)$ received a bolus injection of thiopentone $\left(5 \mathrm{mg} \cdot \mathrm{kg}^{-1}\right)$ alone in $2 \mathrm{ml}$ distilled water.

Systolic arterial pressure, $\mathrm{HR}, \mathrm{PaO}_{2}$ and $\mathrm{PaCO}_{2}$ were measured at $1,3,10$, and $30 \mathrm{~min}$ after the bolus injection. Blood samples were collected at $1,2,3,5$, $7,10,15,20,30,45$, and 60 min after the injection for thiopentone assay.

\section{Plasma thiopentone concentration}

The plasma thiopentone concentration was determined by high performance liquid chromatography based on the method of Blackman et al. ${ }^{2}$ A model ALC/GPC 204 high-performance liquid chromatograph (HPLC) equipped with a Model 441 fixed-wavelength absorbence detector $(214 \mathrm{~nm})$ and $\mu$ Bondapak C18 reversed-phase column (all from Waters, Milford, MA, USA) was used. A 60:40 mixture of acetonitrile-phosphate buffer $(\mathrm{pH}$ 6.5), at a flow rate of $2.0 \mathrm{ml} \cdot \mathrm{min}^{-1}$ was used as a mobile phase. Chromatography was performed at room temperature. After each blood sample was centrifuged at 3000 $\mathrm{rpm}$ for $10 \mathrm{~min} 0.5 \mathrm{ml}$ of the supernatant were transferred to another tube. Fifty microLitres of internal standard solution ( $5 \mathrm{mg}^{\mathrm{kg}}{ }^{-1}$ secobarbital) and $2 \mathrm{ml}$ ethanol $99.5 \%$ was added to the sample. The mixture was vibrated vigorously and placed at room temperature for $15 \mathrm{~min}$ and then centrifuged for $10 \mathrm{~min}$ at $3000 \mathrm{rpm}$. Fifty microLiters of supernatant were injected into the HPLC. A standard linear curve was obtained for a thiopentone concentration of 0.5 to $100.0 \mu \mathrm{g} \cdot \mathrm{ml}^{-1}$ plasma. The minimum sensitivity was $0.5 \mu \mathrm{g} \cdot \mathrm{ml}^{-1}$ plasma with a coefficient of variation for the assay of $3.8 \%$. Thiopentone recovery was $92 \%$.

\section{Pharmacokinetic analysis}

The pharmacokinetic behaviour of the precipitated thiopentone was described using a one-compartment intravenous infusion model. The maximum blood concentration of thiopentone (Cmax), half-life of thiopentone $\left(t^{1 / 2}\right)$, area under the plasma thiopentone concentration-time curve (AUC), and mean residence time of thiopentone (MRT) were calculated according to standard formulae ${ }^{3}$ utilising RSTRIP-2 programme (Micro Math Scientific Software, Salt Lake City, UT, USA).

\section{Histological examination}

At one or $\mathbf{6 0} \mathrm{min}$ after the bolus injection, the rabbit was killed with potassium chloride $i p$. The lungs were removed and fixed in buffered formalin $10 \%$ for three to five days. After sectioning, the lungs were stained with haematoxylin and eosin.

All data are presented as mean \pm SD. Statistical analysis was performed by unpaired $t$ test, and two-way analysis of variance for repeated measurements with a multiple comparison (Scheffe's test) where appropriate. A $P<0.05$ was accepted as statistically significant.

\section{Results}

There were no differences in body weight, heart rate, systolic arterial pressure, $\mathrm{PaO}_{2}$, or $\mathrm{PaCO}_{2}$ between the groups prior to the bolus injection (Table I). Systolic 
arterial pressure in both groups decreased from baseline at one minute after the bolus injection (in the precipitate group, from $141 \pm 6$ to $104 \pm 8 \mathrm{mmHg}, P<0.05$; and in the control group, from $143 \pm 10$ to $106 \pm 7 \mathrm{mmHg}$, $P<0.05)$ and returned to the baseline level at three minutes after the injection. There was no difference between the two groups after the injection. The Cmax of the precipitate group was lower than that of the control group $(P<0.05)$. The $t^{1 / 2}$ of the precipitate group was longer than that of the control group $(P<0.05)$. There was no difference in AUC between the two groups. The MRT of the precipitate group was longer than that of the control group $(P<0.05)$ (Table II). The $\mathrm{PaO}_{2}$ decreased one minute after injection in the precipitate group (432 $\pm 27 \mathrm{mmHg}, P<0.05$ ), but not in the control group $\left(464 \pm 18 \mathrm{mmHg}\right.$ ). $\mathrm{PaO}_{2}$ in the precipitate group returned to baseline three minutes after injection (Figure 1). The $\mathrm{PaCO}_{2}$ did not change throughout the experimental period.

Histological findings showed crystalline structures, 30 to $150 \mu \mathrm{m}$ in diameter, obstructing small arteries in the lungs one minute after bolus injection (Figure 2A, $2 \mathrm{~B}$ ). The crystal-like-material was not identified at 60 min (Figure 2C). Findings of the lungs in the control group one minute after injection were within normal limits (Figure 2D).

\section{Discussion}

The present study showed that the precipitate formed by thiopentone and vecuronium acted as pulmonary emboli and decreased the $\mathrm{PaO}_{2}$ immediately after injection. The plasma decline curve of thiopentone in the precipitate group showed a lower maximum concentration and a longer half-life than in the control group. The MRT of thiopentone was longer in the precipitate group, while the AUC did not differ between the two groups. The MRT is the average time the number of molecules introduced reside in the body. ${ }^{4} \mathrm{~A}$ longer MRT indicates that the thiopentone precipitate does not dissolve in the blood as rapidly after injection. The AUC reflects the total amount of drug within the body. ${ }^{4}$ Compatible AUC values in both groups indicated that the thiopentone precipitate dissolves in the blood gradually and completely. The histological findings demonstrated that crystal-like substances were trapped by the pulmonary capillaries at one minute after the precipitate injection. In addition, a transient decrease of $\mathrm{PaO}_{2}$ was observed after the precipitate injection. These findings indicate that the precipitate caused pulmonary emboli immediately after the injection. Pulmonary emboli caused by the precipitate may have induced the decrease in $\mathrm{PaO}_{2}$. Although the decrease was transient, the precipitate remained in the pulmonary capillaries and dissolved there to result in prolonged MRT.

Precipitate formation with drug admixtures is not uncommon. Collins et al. have reported that precipitates of phenytoin (25 to $50 \mu \mathrm{m}$ in length, $5 \mu \mathrm{m}$ in

TABLE I Baseline data

\begin{tabular}{lll}
\hline & \multicolumn{2}{c}{ Groutp } \\
Measurement & Control $(n=8)$ & Precipitate $(n=8)$ \\
\hline Weight $(\mathrm{kg})$ & $3.0 \pm 0.1$ & $3.0 \pm 0.1$ \\
Pulse $(\mathrm{bpm})$ & $222 \pm 11$ & $230 \pm 10$ \\
$\mathrm{SBP}(\mathrm{mmHg})$ & $143 \pm 10$ & $141 \pm 6$ \\
$\mathrm{PaO}_{2}(\mathrm{mmHg})$ & $464 \pm 30$ & $472 \pm 29$ \\
$\mathrm{PaCO}_{2}(\mathrm{mmHg})$ & $36 \pm 3$ & $34 \pm 3$ \\
\hline
\end{tabular}

All data are expressed as mean \pm SD.

SBP: systolic blood pressure.

TABLE II Pharmacokinetic parameters

\begin{tabular}{|c|c|c|}
\hline Parameter & $\begin{array}{l}\text { Group } \\
\text { Control }(n=8)\end{array}$ & Precipitate $(n=8)$ \\
\hline $\operatorname{Cmax}\left(\mu \mathrm{g} \cdot \mathrm{ml}^{-1}\right)$ & $17.0 \pm 1.6$ & $12.9 \pm 4.5^{\star}$ \\
\hline$t^{1 / 2}(\min )$ & $21.7 \pm 8.2$ & $32.3 \pm 8.5^{\star}$ \\
\hline AUC $\left(\mu \mathrm{g} \cdot \mathrm{min} \cdot \mathrm{ml}^{-1}\right)$ & $180.2 \pm 13.5$ & $208.8 \pm 27.7$ \\
\hline $\operatorname{MRT}(\min )$ & $16.7 \pm 2.5$ & $21.5 \pm 2.2^{\star}$ \\
\hline
\end{tabular}

Mean $\pm \mathrm{SD} .{ }^{*} P<0.05$ vs control group

Cmax: maximum blood concentration of thiopentone; $t^{1 / 2}$ : half-life of thiopentone; AUC: area under the plasma thiopentone concentration-time curve; MRT: mean thioipentone residence time.

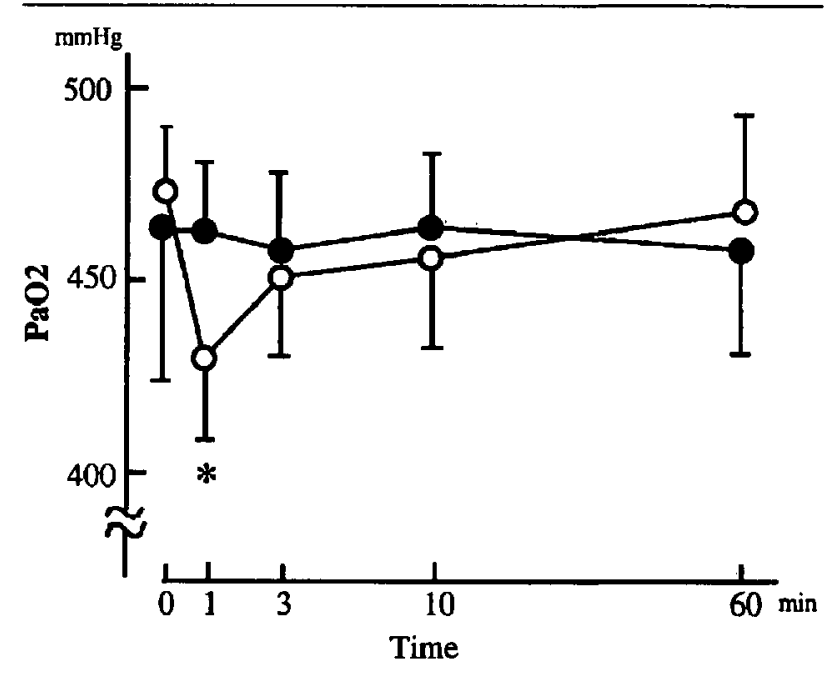

FIGURE 1 Arterial oxygen tension vs time curves after bolus injection. - control group $(n=8) ; 0=$ precipitate group $(n=8)$. Data are expressed as mean \pm SD.

${ }^{\star} P<.05$ compared to the control group. 

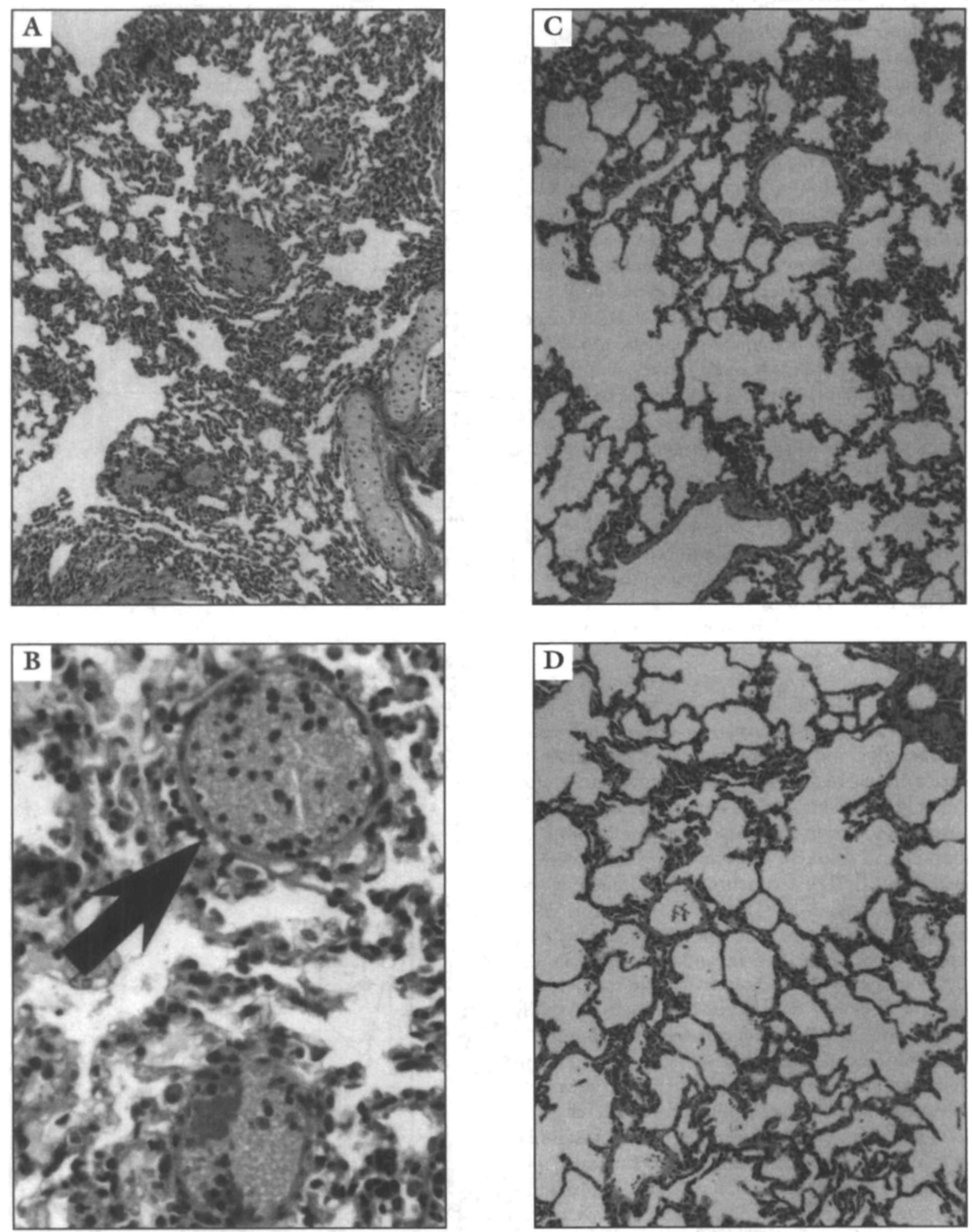

FIGURE 2 Histologic appearance of the rabbit lungs stained with haematoxylin and eosin. The rabbit lungs in the precipitate group at $1 \mathrm{~min}(\mathrm{~A}, \mathrm{~B})$, and at $60 \mathrm{~min}(\mathrm{C})$ after the bolus injection. The rabbit lungs in the control group at $1 \mathrm{~min}$ after the bolus injection (D). The magnification was $100 \mathrm{X}$ for $\mathrm{A}, \mathrm{C}, \mathrm{D}$ and $400 \mathrm{X}$ for $\mathrm{B}$. Arrow in the photograph (B) shows the crystals entrapped in the small arteries of the lung. Findings of all the lungs except that in the precipitate group at 1 min after the injection were within normal limits. 
diameter) formed in a central venous catheter and were of sufficient size to occlude the line..$^{5}$ Allen et al. reported that phenytoin crystals could have deleterious effects in the lungs since they are not likely to pass readily through the pulmonary capillaries ${ }^{6}$ Other drugs such as diazepam and cis- platinum have been reported to precipitate and occlude intravenous lines. The precipitate is also considered to be responsible for pain during injection, episodes of thrombophlebitis, and an increased risk of emboli. ${ }^{7-11}$ The present study demonstrated that the precipitate of thiopentone formed from thiopentone and vecuronium acted as pulmonary emboli.

The present study raises several questions. We deliberately premixed thiopentone and vecuronium, and used a large dose of vecuronium. We do not premix these two drugs and do not use $0.67 \mathrm{mg} \cdot \mathrm{kg}^{-1}$ vecuronium in clinical practice. However, when the precipitate occludes the infusion line in clinical practice, the size of the precipitate is $>1 \mathrm{~mm}$ in diameter. In order to regulate the size of the precipitate to $>1$ $\mathrm{mm}$ diameter, the drugs were mixed and a large dose of vecuronium was used. We measured $\mathrm{PaCO}_{2}$, but not end-tidal $\mathrm{PCO}_{2}$ although this may have allowed respiratory dead space to be calculated.

In conclusion, the precipitate formed by thiopentone and vecuronium produced pulmonary emboli and decreased $\mathrm{PaO}_{2}$ immediately after the injection. To avoid precipitate formation we recommend a thorough flush of the intravenous tubing after the injection. If the precipitate forms in the tubing, it should be removed before it enters the vein, for example, exchanging the infusion line.

\section{References}

1 Tanigucbi $T$, Yamamoto $K$, Kobayashi $T$. The precipitate formed by thiopentone and vecuronium. Can J Anaesth 1996; 43: 511-3.

2 Blackman GL, Jordan GJ. Analysis of thiopentone in human plasma by high-performance liquid chromatography. J Chromatogr 1978; 145: 492-5.

3 Hull CJ. General principles of pharmacokinetics. In: Prys-Roberts C, Hug CC Jr (Eds.). Pharmacokinetics of Anaesthesia. Oxford: Blackwell Scientific Publications, 1984: 1-24.

4 Rowland M, Tozer TN. Clinical Pharmacokinetics. Concepts and Applications, 3rd ed. Philadelphia: Lea \& Febiger, 1995: 469-89.

5 Collins $\pi$, Lutz RJ. In vitro study of simultaneous infusion of incompatible drugs in multilumen catheters. Heart Lung 1991; 20: 271-7.

6 Allen LV Jr, Levinson RS, Phisutsinthop D. Compatibility of various admixtures with secondary additives at
Y-injection sites of intravenous administration sets. Am J Hosp Pharm 1977; 34: 939-43.

7 Lutz RJ, Dedrick RL, Boretos JW, Oldfield EH, Blacklock $J B$, Doppman $J L$. Mixing studies during intracarotid artery infusions in an in vitro model. J Neurosurg 1986; 64: 277-83.

8 TarrBD, Yalkowsky SH. A new parenteral vehicle for the administration of some poorly water soluble anticancer drugs. J Parenter Sci Technol 1987; 41: 31-3.

9 Yalkowsky SH, Valvani SC, Johnson BW. In vitro method for detecting precipitation of parenteral formations after injection. J Pharm Sci 1983; 72: 1014-7.

10 Scbroeder $H G$, DeLuca PP. Particulate matter assessment of a clinical investigation on filtration and infusion phlebitis. Am J Hosp Pharm 1976; 33: 543-6.

11 Flynn GL. Solubility concepts and their applications to the formulation of pharmaceutical systems. J Parenter Sci Technol 1984; 38: 202-9.

12 Benumof JL. Respiratory physiology and respiratory function during anesthesia. In: Miller RD (Ed.). Anesthesia, 4th ed. New York: Churchill Livingstone, 1994: 594-600. 